University of Nebraska - Lincoln

DigitalCommons@University of Nebraska - Lincoln

Winter 1-7-2014

\title{
A Life History Perspective on Skin Cancer and the Evolution of Skin Pigmentation
}

\author{
Daniel L. Osborne \\ University of Nebraska - Lincoln, dosborne2@unl.edu \\ Raymond B. Hames \\ Universit of Nebraska Lincoln, rhames2@unl.edu
}

Follow this and additional works at: https://digitalcommons.unl.edu/anthropologyfacpub

Part of the Biological and Physical Anthropology Commons

Osborne, Daniel L. and Hames, Raymond B., "A Life History Perspective on Skin Cancer and the Evolution of Skin Pigmentation" (2014). Anthropology Faculty Publications. 56.

https://digitalcommons.unl.edu/anthropologyfacpub/56

This Article is brought to you for free and open access by the Anthropology, Department of at DigitalCommons@University of Nebraska - Lincoln. It has been accepted for inclusion in Anthropology Faculty Publications by an authorized administrator of DigitalCommons@University of Nebraska - Lincoln. 


\title{
A life history perspective on skin cancer and the evolution of skin pigmentation
}

\author{
Daniel L. Osborne and Raymond Hames \\ Department of Anthropology, University of Nebraska-Lincoln, Lincoln, Nebraska, USA
}

Corresponding author - Daniel L. Osborne, Department of Anthropology, University of Nebraska-Lincoln, 810 Oldfather Hall, P.O. Box 880368, Lincoln, NE 68588-0368, USA; email dosborne2@unl.edu

\begin{abstract}
The ancestral state of human skin pigmentation evolved in response to high ultraviolet radiation (UVR) stress. Some argue that pigmentation evolved to limit folate photolysis, therein limiting neural tube defects. Pigmentation also protects against sunburn which decreases the efficiency of sweating and potentiates skin infection. Pigmentation increases the efficacy of skin as a barrier to infection. Skin cancer has been rejected or minimized as a selective pressure because it is believed to have little or no effect on mortality during reproductive years. This argument ignores evidence of human longevity as a derived life history trait and the adaptive value of investment in offspring and kin, particularly during the post-reproductive lifespan. Opponents argue that lifespan in prehistoric hunter-gatherers was too short to be relevant to the evolution of skin pigmentation. This argument is flawed in that it relies on estimates of longevity at birth rather than adolescence. When appropriate estimates are used, it is clear that human longevity has a deep evolutionary history. We use a life history perspective to demonstrate the value of skin pigmentation as an adaptation to skin cancer with the following points: UVR exposure increases dysregulation of gene expression in skin cells leading to immortal cell lines; cutaneous malignant melanoma (CMM) affects individuals throughout reproductive years; and lifespan was longer than has previously been acknowledged, providing the opportunity for kin selection. This hypothesis is not at odds with the folate or barrier hypotheses. We stress that the evolution of skin pigmentation is complex and is an ongoing process.
\end{abstract}

Keywords: skin cancer, UVR, longevity, life history

Beginning in the early 1950s a number of researchers have argued that human skin coloration is an adaptation to protect against skin cancer by blocking the harmful effects of UVA and UVB radiation (Daniels et al., 1972). A number of lines of evidence have been used to test this hypothesis. For example, Fear et al. (1976, cited in Beall and Steegman, 2000; p 199, Fig. 7.6) show that in the United States skin cancer rates and mortality are negatively correlated with latitude. In the state of Texas, skin cancer rates were approximately five times greater for light-skinned people compared with dark-skinned people. Other studies in Australia and New Zealand compared skin cancer rates of light-skinned individuals to aboriginal residents (e.g., Haynes et al., 2008; Sneyd and Cox, 2009; Olsen et al., 2012). The results were consistently the same: lighter-skinned individuals had higher skin cancer rates. To our knowledge no one disputes the association between skin color, the intensity of UV radiation, and skin cancer. Over the last 20 years there has been growing support for an alternative but not clearly contradictory hypothesis for skin coloration that we call the folate hypothesis as outlined by Jablonski and Chaplin (2000) and Jablonski (2010). The authors assemble impressive evidence that dark skin in high UV environments prevents the degradation of folic acid synthe- sis and ultimately folate production, thus preventing a host of problems from neural tube defects in infants to male infertility (see Elias and Williams, 2013, for a rebuttal). However, in low UV environments the problem may be allowing sufficient UV radiation in through the skin to stimulate vitamin D synthesis to prevent problems in bone formation, cognitive development, and immune function, leading to light skin as the adaptive solution. A more recent, intriguing hypothesis is that depigmentation evolved as an energy-sparing mechanism (Elias and Williams, 2013). In the process of promoting the folate hypothesis Jablonski (2010) argues that although skin cancer is reliably associated with UV radiation and skin color, the typical onset of skin cancer is at about the time when one's reproductive career is ending: therefore, dark skin would not have a selective effect in preventing skin cancer. Elias and Williams (2013) dismiss the selective potential of skin cancer using this same reasoning. For a variety of reasons stemming from a new understanding of human life history and inclusive fitness theory, detailed below, we argue that preventing skin cancer after reproduction is likely adaptive. And while a full review of this literature is beyond the scope of this article, we provide a synthesis of recent research on the dangers of skin cancer and their likely impact on fitness. 
Table 1. Melanoma Incidence across a range of locations

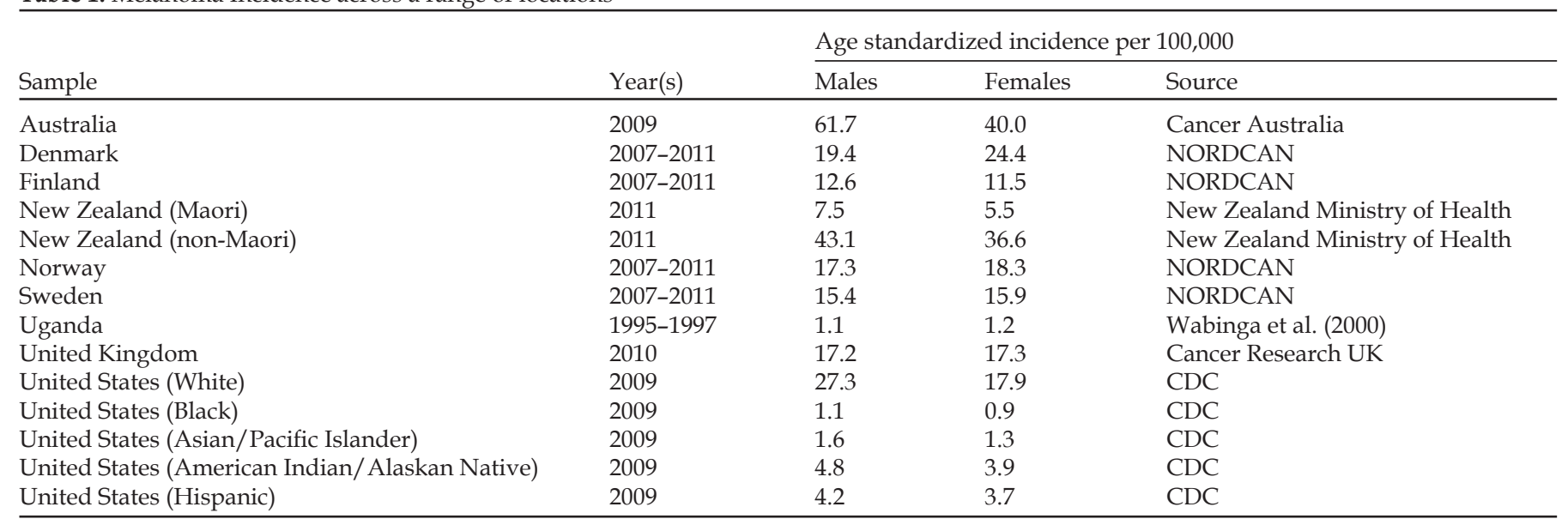

\section{Skin cancer types}

Skin cancer presents as a range of disorders associated with abnormal growth of skin cells which develop into lesions classified as preskin cancer or skin cancer. Some skin cancers occur more frequently than others and are more relevant to fitness. The most common skin cancers are named for the cutaneous cells from which they arise and include the nonmelanoma skin cancers (NMSC) basal cell carcinoma (BCC) and squamous cell carcinoma (SCC), and cutaneous malignant melanoma (CMM).

Exposure to ultraviolet radiation (UVR) increases risk of developing NMSC and CMM, though there is also a genetic predisposition (Lacour, 2002; Epstein, 2008; Nan et al., 2009; Scherer and Kumar, 2010). Rates of NMSC are estimated to have increased by 77\% from 1992 to 2006 (Scherer and Kumar, 2010; Stern, 2010). This increase could be due to atmospheric changes, migration of lightly pigmented populations to lower latitudes, improvements in diagnosis, changes in sun-seeking behavior, and access to artificial UVR.

On a general scale, likelihood of metastasis in CMM is greater than in NMSC and if not treated early this cancer has high mortality. Like all skin cancers, lightly pigmented populations are at greater risk of developing CMM, although it is present in more darkly pigmented populations in lower proportions (Table 1; also see Camain et al., 1972; Soeripto et al., 1977; Bang et al., 1987; Neugut et al., 1994; Yakubu and Mabogunje, 1995; Sneyd and Cox, 2009). Accordingly, one cannot easily dismiss skin cancer as a selective pressure in the adaptation to UVR. The literature on skin cancer contains relatively few publications on risk and pathophysiology in more darkly pigmented populations (Yakubu and Mabogunje, 1995; Sneyd and Cox, 2009). Because moles present at birth can develop into CMM, some have questioned whether or not UVR has an effect on CMM (Tucker, 2008). This rejection of UVR as a driver of CMM rests largely on the heritability of this disease.

\section{Skin cancer genetics}

Genes associated with skin cancer risk remain poorly understood. Some genetic markers (e.g., MC1R, ASIP, TYR,
EXOC2, UBAC2, OCA2, SLC24A5, SLC24A4, MATP, IRF4, and the $1 p 36$ and $1 q 42$ loci) have been identified as risk factors independent of skin pigmentation, though they only explain a small amount of variation in skin cancer risk (Han et al., 2008; Scherer and Kumar, 2010). Because genome-wide associations studies (GWAS) have not identified regions that explain heritability, some have proposed that many "small-effect" genes are responsible for this variation - although others contest that current models do not include large enough regions of the genome to conclude anything about the genetic basis of skin cancer (Vazquez et al., 2012).

One possible reason that genes with strong effects on skin cancer have not been identified could be the focus on coding regions. Mutations in the promoter regions of genes can affect trait expression and are affected by UVR, providing a clear gene $\times$ environment interaction (Greenman, 2007; Ikehata et al., 2008; Singh et al., 2012; Tewari et al., 2012; Huang et al., 2013). Mutations in telomerase reverse transcriptase (TERT) gene promoter regions are more likely to produce immortal cell lines conducive to oncogenesis than are mutations to coding regions (Huang et al., 2013). Two byproducts of UVR exposure are cyclobutane pyrimidine dimers (CPDs) - mainly thymine dimers (TTs) - and 6,4-photoproducts (6,4 pyrimidine-pyrimidones) (Ikehata et al., 2008; Rünger, 2008; Tewari et al., 2012). Both CPDs and 6,4-photoproducts are associated with melanoma oncogenesis. Cyclobutane pyrimidine dimer (CPD) formation from UVB exposure has been suggested as a strong selective pressure for dark pigmentation, but UVA was not considered a source of CPD or an important factor in the evolution of skin pigmentation (Jablonski and Chaplin, 2010). Based on these results UVA may be more carcinogenic than was previously assumed. This is especially important in evolutionary contexts because UVA is more abundant than UVB, increasingly so at higher latitudes, and may have played a more significant role in the evolution of skin pigmentation than was previously thought.

\section{Skin cancer as a selective force in skin pigmentation}

Skin cancer has been dismissed or downplayed as a selective force in the evolution of skin pigmentation because it is argued to affect individuals as their reproductive 
Table 2. Life Expectancy at birth, age 15, and age 45 in 5 Unacculturated Hunting and Gathering Societies and USA in 2008

\begin{tabular}{llll}
\hline Group & $e_{0}$ & $e_{15}$ & $e_{45}$ \\
\hline Kung & 36 & 38.1 & 19.7 \\
Hadza & 34 & 42.5 & 24.2 \\
Hiwi & 27 & 32.5 & 17.9 \\
Ache & 37 & 38.5 & 21.1 \\
Agta & 21 & 28.6 & 13.7 \\
USA 2008 & 78.1 & 63.8 & 35.5 \\
\hline
\end{tabular}

Source: Kaplan and Gurven (1997; p 327, Table 2) for tribal groups and CDC's http://www.cdc.gov/nchs/data/nvsr/nvsr61/nvsr61_03.pdf, p. 4, Table B for USA.

careers are ending (Jablonski and Chaplin, 2000; Juzeniene et al., 2007; Elias and Williams, 2013). Jablonski and Chaplin (2012) observe that skin cancer is a disease of modernity, primarily affecting individuals living at lower latitudes than their ancestral environment and/or engaging in the tanning culture. Sun-seeking and tanning behavior does increase the risk of skin cancer and thus continues as a selective pressure on skin pigmentation. The claim that the onset of skin cancer occurs late in an individual's reproductive career, however, is not completely correct. For example, $\mathrm{CMM}$ is the third most common cancer in adolescents and young adults in the US and typically affects individuals throughout the reproductive period (ages 20-45), so this argument does not hold for the deadliest form of skin cancer (Diepgin and Mahler, 2002; Weir et al., 2011). The selective potential of CMM is best appreciated through an understanding of survival time following diagnosis. A meta-analysis of late stage CMM found that prior to 1985 the median time to death was 5.8 months (Lee et al., 2000; Mervic, 2012). Research conducted between 1985 and 2000 found the median time to death was 8.9 months. Although these rates are based on individuals with late stage CMM, they also assume some level of medical intervention, suggesting that during the evolution of skin pigmentation this disease would have been a strong source of selection. Further, Robins (1991) argues that selection of dark skin should not be contextualized solely in adults, as infants would also have been exposed to UVR. Although this particular argument is made in support of sunburn as a selective pressure in pigmentation, the strong relationship between lifetime UVR exposure and skin cancer risk suggests that infancy may have been relevant in the selection of skin pigmentation.

Research on evolution of skin pigmentation has focused on global variation in relation to UVR exposure as well as barrier competency. In accordance with Gloger's Rule, more darkly pigmented populations live closer to the equator, with skin pigmentation decreasing at higher latitudes. Because dark skin in humans is believed to have evolved in equatorial locations high in UVR, models describing the effects of migration to higher latitudes on darkly pigmented groups have been used to model the evolution of depigmentation in low UVR environments, perhaps in response to insufficient synthesis of vitamin D3 (Jablonski and Chaplin, 2000, 2012). This approach has been critiqued when examining lightly pigmented populations subsequent to migration to low latitudes. Rather than modeling skin cancer as a selective agent, some argue that dark skin evolved in response to UVR-induced nutrient photolysis (Branda and Eaton, 1978; Jablonski, 1999; Jablonski and Chaplin, 2000, 2012) and others posit that pigmentation evolved to increase barrier functionality as a defense against infection. The paucity of data on skin cancer incidence in darkly pigmented populations limits our understanding of these disorders as selective pressures. When considering darkly pigmented populations living in high UVR environments, it is clear that skin cancer is present at a lower incidence than in lightly pigmented groups (Bang et al., 1987; Johnson et al., 2003).

Following Blum (1961), Jablonski and Chaplin (2010), and Elias and Williams (2013) dismiss the utility of dark pigmentation as an adaptation to skin cancer because it is perceived to affect individuals beyond reproductive age. Jablonski and Chaplin (2010) write, "With early reproduction and before the extension of the average human lifespan through improvements in diet and medicine, skin cancer had no effect on reproductive success" (8966). This dismissal rests on two now dubious claims: (1) low average longevity in evolutionary relevant human societies (hunter gatherers) compared with present day societies, and (2) empirical studies of inclusive fitness behaviors of postreproductives.

The argument made by Blum which underwrites the claim of no or little effect on reproductive success was made in 1961. This dismissal has found its way into the literature (e.g., Juzeniene et al., 2009; Elias and Williams, 2013) and the human variation section of the American Anthropological Association's website - http://www. understandingrace.org/humvar/skin_01.html . While reasonable at the time, three major developments postdating Blum's dismissal make such claims dubious. First, there is good evidence that contemporary hunter-gatherers can live into their 60s (Kaplan and Gurven, 2007; p 236; see Table 2). This new comparative research shows that normal human lifespans are much longer than has been previously thought and suggests that longevity has a deep human history, perhaps dating to the evolution of anatomically modern humans, and is not solely a recent consequence of advanced medicine or public health measures. Second, inclusive fitness theory (Hamilton, 1964) demonstrates that indirect reproduction through kin investment (kin selection) is an avenue for fitness for postreproductive individuals. And third, the evolution of longevity and corresponding slow life history in humans suggest that investment in offspring extends beyond the period of subadulthood leading to additional avenues for inclusive fitness (Hawkes et al., 1998; Peccei, 2001). Clearly, points 2 and 3 are interconnected. We elaborate each of these points in turn.

\section{Longevity among hunter-gatherers}

While it is abundantly clear that human life expectancy at birth has increased dramatically since 1900 (Finch, 2012; Burger et al., 2012) humans, prior to that time, were a long-lived species. There is good reason to believe that human longevity has not changed sufficiently in recent times such that early death in the context of evolved longevity would have no effect on fitness. Kaplan and Gurven's (2007) comparative sample of longevity among contemporary hunter-gatherers and horticulturalists (with a strong dependence on foraging) is the largest of its kind to date. They examined 19 different subsistence societies including 5 hunter-gatherer groups with little contact, 
4 different forager-horticulturalists, and 9 acculturated hunter-gatherer groups. Claims about the recent extension of longevity and corresponding belief in short longevity of hunter-gatherers is often mistakenly misrepresented by life expectancy at birth estimates $\left(e_{0}\right)$, which range from 21 to 37 years among uncontacted huntergatherers (Kaplan and Gurven, 2007; p 326). However, if one examines life expectancy at age 15 -the average number of additional years of life-among traditional hunter-gatherers, $64 \%$ reach age 45 (Table 2). And, on average, traditional hunter-gatherers who reach age 45 will have two decades of life left (Kaplan and Gurven, 2007; p 326). Kaplan and Gurven (2007; p 348) conclude, "Post-reproductive longevity is a robust feature of hunter-gatherers and of the life cycle of Homo sapiens. Survivorship to grandparental age is achieved by over two-thirds of people who reach sexual maturity and can last an average of 20 years" (see also Finch, 2010; p 1723). More to the point, Levitis et al. (2013) developed "Postreproductive Representation," a measure ultimately demonstrating that postreproductive life is a derived evolutionary trait of humans and not a consequence of modern increases in human lifespan. It is defined "as that proportion of adultyears lived which are postfertile" (2013; p 68). The figures for humans range from 0.315 to 0.5 in tribal populations and up to 0.76 in modern populations. The corresponding figure for wild chimps is 0.018 .

One could argue that contemporary hunter-gatherers are not representative of prehistoric populations because paleodemographic estimates of longevity based on human remains generally show significantly lower survivorship than those attained by Kaplan and Gurven. As noted by Kaplan and Gurven (2007; p 334) paleodemographic estimates are beset by a variety of problems such as sampling biases (e.g., Wood et al., 1992) that typically lead to lower estimates than documented in contemporary hunter-gatherers. And it is not unreasonable to argue that contemporary hunter-gathers exist in a more difficult epidemiological landscape because of STDs, tuberculosis, and other diseases that have recently entered their populations through contact with more complex societies. More to the point, there is little evidence that the subsistence landscapes in the past were significantly different than the landscapes of contemporary hunter-gatherers. The environment of current hunter-gatherers sampled by Kaplan and Gurven (Hadza, Ache, Kung, Hiwi, and Agta) ranges from desert to savannah to tropical forest locations which the first humans occupied, suggesting that their results apply to a moderately wide range of low-latitude, evolutionarily relevant environments.

Longevity and individual and kin effects. The obvious question one must answer is that given that longevity is not an artifact of modern conditions what can humans do to enhance their reproductive success after direct reproduction is no longer possible or sharply diminished? The short answer to this question is the enhancement of inclusive fitness through one's positive effects on the reproductive success of kin (Hamilton, 1964). There is now considerable evidence that humans behave in ways to enhance the fitness of close kin (Cronk, 1991; Voland, 1998; Barrett et al., 2002; Gaulin and McBurney, 2003; Hames, in preparation). This is especially critical for females because of menopause, whereby they lose the ability to reproduce directly between the ages of 40 and 45 even though they will live another two decades, on average. We will first examine this issue from a female perspective and then turn to males.

As noted by Hawkes et al. (1997), the problem of female longevity in the context of menopause was first considered by G. C. Williams (1957), who argued that the riddle of human menopause could be solved through investment in children or grand offspring. A particular version of this view became known as the "grandmother hypothesis" that argues that grandmothers enhanced their inclusive fitness by either enhancing the fertility of daughters or the survivorship of grand offspring (Hawkes et al., 1997) through food transfers, child care and other acts of assistance. In a modified version of this hypothesis known as the "mother hypothesis" Peccei (2001) argues that since a woman's last child is not fully independent of parental investment for about 16 to 18 years, the survivorship of a woman's last child would be diminished if she were not to live long enough assist that child through the juvenile period. Comparative data on economic independence (when food production is equal to or greater than consumption) shows Peccei (2001) is reasonably accurate (Kaplan, 1997; Kramer 2005).

Over the last 10 years or so considerable evidence has accumulated to support the grandmother hypothesis, showing that postreproductive women are able to enhance their inclusive fitness through such means as increasing the fertility of daughters and ensuring the survivorship of grandoffspring. This research highlights the adaptive value of longevity-inclusive fitness effects even when direct reproduction ceases. Sear and Mace (2008) reviewed 45 studies investigating the presence of mostly senior kin (mothers, fathers, grandparents, older siblings) on the fertility of reproductive-aged women and the survivorship of their children. The presence of a maternal grandmother was associated with an increase in her grandchildren's probability of surviving in $69 \%$ of the cases (9 of 13), and for paternal grandmothers it was 53\% (9 of 17 studies) (2008; Table 3, p 8).

It is consistently shown that since males do not go through menopause and marry polygynously or engage in serial monogamy they continue to engage in direct reproduction until near the end of their lives. For example, among the polygynous Yanomamö, male fertility peaks between ages 25 and 55 and steadily declines thereafter (Melancon, 1982; p 175, Fig. 9.2). Furthermore, polygyny is more frequently allowed by foragers than in other economic formations (Marlowe, 2003). Consequently, male reproductive careers through polygyny or serial monogamy can last decades beyond that of females (See Josephson, 2002 for a cross-cultural survey).

While there are numerous studies showing how postmenopausal women can enhance their direct fitness by continuing to survive and invest in current dependent offspring or grandoffspring there are few showing the same for men. However, recent research by Scelza (2010) shows that fathers play important social roles for their sons among Martu hunter-gatherers. Her Martu data show that men who have fathers are likely to go through ritual initiation to manhood earlier (a prerequisite for marriage) and marry earlier, and have higher fertility at age 30 compared with males who lacked living fathers who could sponsor them and therefore went through initiation later. 
We have shown that human longevity is not a recent phenomenon and that postreproductive humans can enhance their inclusive fitness by increasing the survivorship and fertility of offspring and close kin. Therefore, we believe that the evidence cited above casts serious doubts on claims that skin coloration's protective value is not an adaptation for the prevention of relatively late onset skin cancer.

\section{Modern rates of skin cancer and tests of adaptive hypotheses}

Jablonski and Chaplin (2010:2) acknowledge the value of dark skin in protecting against skin cancer in the following: "Skin cancers are mostly a consequence of modern human migrations and resulting mismatches between skin pigmentation and geography or lifestyle."

We agree with their mismatch hypothesis. The key point they make is that dark skin protects against skin cancers. To understand the value of dark skin, we can think of no better natural experiment (Beall and Steegman, 2000; $p$ 201) than to examine skin cancer rates of those whose ancestral homelands were in low UV environments but who currently grew up and live in higher UV environments. If dark skin coloration is a protective response to skin cancer then light skinned individuals should show greater skin cancer rates than their dark-skinned ancestors who continue to live in their aboriginal homelands.

Skin cancer incidence rates for darkly pigmented populations living at low latitudes are few. This is due in part to the lower incidence rates in these groups relative to lightly pigmented populations - since the latter have higher mortality rates from skin cancer, research is focused on combating this issue. The limited data suggest that both NMSC and CMM are present in equatorial populations (Camain et al., 1972; Soeripto et al., 1977; Yakubu and Mabogunje, 1995). Yakubu and Mabogunje (1995) tracked incidence in a Nigerian sample $(n=721)$ over an 11-year period, including comparative data in their analysis. The authors report $24 \%$ of subjects developed skin cancer on the head and neck with $86 \%$ of those cases being SCC - their ages ranged from 4 months to 75 years, with a median age of 39 years. While BCC normally dominates cancer of the head and neck, this does not appear to be the case for this Nigerian sample. Camain et al. (1972) report that SCC was the most frequent type of skin cancer in their sample from Senegal, though most tumors presented on the lower limbs rather than the head and neck. Soeripto et al. (1977) report skin cancer frequency in Indonesians, finding that skin cancer accounted for $17.6 \%$ of tumors in males and $9.6 \%$ in females - though the authors note that the value for females is suppressed due to high frequencies of genital tumors. Some have argued that disparate skin cancer rates between African albinos and nonalbinos support skin cancer as a selective pressure for pigmentation (e.g., Robins, 1991). Albinos are known to suffer from skin cancer at a much higher rate (Lookingbill et al., 1995; Yakubu and Mabogunje, 1995) than non-albinos at any latitude, and because this trait occurs in Africa we might interpret the data as evidence of the selective potential of skin cancer. Albinism is associated with the inability to produce melanin at all, so it could also be argued that such a model is an unrealistic proxy for ancestral skin pigmentation. Even without the albinism data, this research demonstrates the presence of skin cancer in equa- torial populations, though estimating change in incidence rates over time is not possible given the paucity of data (Yakubu and Mabogunje, 1995). Additionally, it is likely that skin cancer in developing nations is underreported.

In addition to skin cancer incidence rates among populations living in place, populations that have migrated from their ancestral latitude to more equatorial climates provide a natural experiment with which to judge the differential effect of UVR on lightly and darkly pigmented groups. It is widely accepted that lightly pigmented groups living at low latitudes will suffer from skin cancer at a higher rate than populations with darker pigmentation in the same region (e.g., Lomas et al., 2012). Beall and Steegman (2000) demonstrated this relationship in a sample of African-Americans and whites living in Texas, arguing that this natural experiment supported skin cancer as a selective agent in skin pigmentation. This discrepancy is also illustrated by CMM incidence in Maori and non-Maori subjects living in New Zealand. The distance that sun-sensitive populations living near the equator have traveled from their ancestral latitude is substantial and likely would not have occurred during prehistory, but contemporary skin cancer incidence demonstrates the clear adaptive benefit of dark skin pigmentation against UVR. Skin cancer has been a major health issue in these groups and the data support an increase in skin cancer incidence over time (e.g., Birch-Johansen et al., 2010). Increases in skin cancer incidence are also likely influenced by changing attitudes toward sun-seeking behavior and atmospheric depletion of ozone (Buller et al., 2011; Lemus-Deschamps and Makin, 2012).

The relationship between UVR and skin cancer may not be as clear as was once believed. CMM risk may also be influenced by the presence of skin damaged by scarring, tattoos, or burns (Camain et al., 1972; Chadwick et al., 2012). Body modification occurs in contemporary human cultures and is likely not a novel behavior in humans. For example, Sosis et al. (1997; p 242) show that tattooing and scarification occur in over half of the societies in the HRAF probability sample. Because modification of the skin-both intentional and accidental-can decrease the amount of melanin present at the site of injury (Chadwick et al., 2012), this raises the opportunity for CMM to be a selective agent associated with body modification and may help explain oncogenesis in skin not normally subjected to UVR. This may also support the claim that skin pigmentation evolved in response to infection, as more darkly pigmented skin is more resilient to this stress.

Further, Moan et al. (2008) argue that vitamin D3 has a protective effect on cancers -including skin cancers. The negative relationship between latitude and CMM is well established. The relationship between skin cancer death rate and latitude, however, is more complicated. The authors evaluated skin cancer incidence and death rate in individuals of European descent living in Australia, New Zealand, Sweden, Denmark, Norway, and the UK (Moan et al., 2008). As an additional control, the authors only included individuals that either never tan and always burn (type I skin), or those who almost always burn and occasionally tan (type II skin). Not surprisingly, subjects living in Australia and New Zealand were affected by CMM at a higher rate than were subjects living in Europe. But incidence rates relative to death rates of Australian and New Zealand subjects were actually lower than subjects 
living in Europe. This suggests that while CMM incidence rates are higher in Australia and New Zealand, individuals who develop CMM at higher latitudes have higher mortality. The authors owe this relationship in part to the greater availability of UVB-induced vitamin D3 synthesis. These samples share common ancestries and had lightly pigmented skin, providing some degree of control, but variation in exposure to carcinogens, diet, and healthcare cannot be ruled out as possible factors. Darkly pigmented individuals tend to present with thicker tumors and suffer from faster disease progression than lightly pigmented individuals (Johnson et al., 2003; Gloster and Neal, 2006; Haynes et al., 2008; Sneyd and Cox, 2009; Wu et al., 2011), which may be due to lower levels of vitamin D3 though delayed diagnosis and differential access to healthcare may also be at play.

Murine models support the relationship between vitamin D3 and skin cancer. BCC, SCC, and CMM all have the vitamin D (1,25-dihydroxyvitamin D3) receptorVDR - suggesting that vitamin D3 plays some role in development and progression of skin cancer (Bikle, 2012). Mice lacking the VDR develop skin tumors after exposure to a carcinogen (Zinser et al., 2002) or UVB (Ellison et al., 2008). Other murine models have demonstrated that vitamin D3 suppresses Hedge Hog $(\mathrm{HH})$ proliferation and signaling responsible for $\mathrm{BCC}$, independent of the VDR (Tang et al., 2011). Additionally, topical application of vitamin D3 to cancerous lesions also slows HH proliferation and signaling. Bikle (2012) argues that in addition to controlling proliferation and differentiation of $\mathrm{HH}$, the wnt/ $\beta$-catenin pathways, immunoregulation, and DNA repair are also likely mediated by vitamin D3. Higher levels of D3 increase repair capacity. Complicating matters further, folate also repairs DNA damage, with capacity for DNA repair being highest with increased folate (Williams et al., 2012). High UV-induced D3 might share a negative relationship with folate, all things being equal. If D3 and folate are low, then DNA repair is seriously hindered. So disentangling the relationship between D3, folate, and skin cancer complicates matters, but does not necessitate rejecting the skin cancer hypothesis.

\section{Conclusions}

We have presented several lines of evidence in support of skin cancer as a selective agent in skin pigmentation. Rejected by some due to its perceived delayed age at onset, data now support CMM as a disorder affecting individuals throughout their reproductive years. It is also now clear that longevity has a deeper evolutionary history than once assumed and that kin selection can have a positive effect on fitness. Though less deadly, the late-developing NMSCs could be selective when viewed through the lens of life history theory and kin selection. The evidence for epigenetic change provides a model demonstrating the adaptive value of dark skin in high UVR environments. Epigenetic change can produce comparatively rapid changes in phenotype in response to environmental cues and is consistent with claims of skin pigmentation as a labile trait. Many issues remain, however, as future research must disentangle the relationships between UVR, skin cancer, skin damage, barrier functions, vitamin D3, and folate. Research on the evolution of skin pigmentation in groups who underwent some degree of selection for depigmentation would offer interesting perspectives on this matter-particularly in populations living at high altitudes where UVR intensity is high.

Acknowledgments - The authors thank the anonymous reviewers from American Journal of Physical Anthropology for useful commentary on earlier versions of this article.

\section{Literature Cited}

Bang KM, Halder RM, White JE, Sampson CC, Wilson J. 1987. Skin cancer in black Americans: A review of 126 cases. J Natl Med Assoc 79:51-58.

Bastiaens MT, ter Huurne JAC, Kielich C, Gruis NA, Westendorp RGJ, Vermeer BJ, Bavinck JNB. 2001. Melanocortin-1 receptor gene variants determine the risk of nonmelanoma skin cancer independently of fair skin and red hair. Am J Hum Genet 68:884-894.

Beall CM, Steegmann T. 2000 Human adaptation to climate: Temperature, ultraviolet radiation, and altitude. In: Stinson S, Bogin B, Huss-Ashmore R, O'Rourke DH, editors. Human biology: An evolutionary and biocultural perspective. New York: Wiley-Liss. p 163-210.

Bikle DD. 2012. Protective actions of vitamin D in UVB induced skin cancer. Photochem Photobiol Sci 11:1808-1816.

Birch-Johansen F, Jensen A, Mortensen L, Olesen AB, Kjær SK. 2010. Trends in the incidence of nonmelanoma skin cancer in Denmark 1978-2007: Rapid incidence increase among young Danish women. Int J Cancer 127:2190-2198.

Blum H. 1961. Does the melanin pigment of human skin have adaptive value? An essay in human ecology and the evolution of race. Q Rev Biol 36:50-63.

Blurton Jones NG, Marlowe FW, Hawkes K, O'Connell JF. 2000. Paternal investment and hunter-gatherer divorce rates. In: Chagnon N, Irons W, Cronk L, editors. Adaptation and human behavior: An anthropological perspective. New York: Aldine de Gruyter. p 69-90.

Buller DB, Cokkinides V, Hall HI, Hartman AM, Saraiya M, Miller E, Paddock L, Glanz K. 2011. Prevalence of sunburn, sun protection, and indoor tanning behaviors among Americans: Review from national surveys and case studies of 3 states. J Am Acad Dermatol 65:S114.e1-S114.e11.

Burger O, Baudisch A, Vaupel J. 2012. Human mortality improvement in evolutionary context. Proc Natl Acad Sci USA 109:18210-18214.

Camain R, Tuyns AJ, Sarrat H, Quenum C, Faye I. 1972. Cutaneous cancer in Dakar. J Natl Cancer Inst 48:33-49.

Cancer Australia. A national government agency working to reduce the impact of cancer on all Australians. Cancer Australia Latest News. Australian Government. Online: http:// canceraustralia.gov.au/. Accessed July 30, 2013.

Cancer Research UK. Cancer incidence statistics. Cancer Research UK. Online: http://www.cancerresearchuk.org/ cancer-info/cancerstats/incidence/. Accessed August 9, 2013.

Centers for Disease Control and Prevention. Cancer data and statistics. Online: http://www.cdc.gov/cancer/dcpc/ data/index.htm . Accessed August 5, 2013.

Coall D, Hertwig R. 2010. Grandparental investment: past, present, and future. Behav Brain Sci 33:1-59.

Cronk L. 1991. Human behavioral ecology. Annu Rev Anthropol 20:25-53.

Daniels F, Post PW, Johnson BE. 1972. Theories of the role of pigment in the evolution of human races. In: Riley $\mathrm{V}$, editor. Pigmentation: Its genesis and biologic control. New York: Appleton, Century, Crofts. p 13-22. 
de Vries E, Trakatelli M, Kalabalikis D, Ferrandiz L, Ruiz-deCasas A, Moreno-Ramirez D, Sotiriadis D, Ioannides D, Aquilina S, Apap C, Micallef R, Scerri L, Ulrich M, Pitkanen S, Saksela O, Altsitsiadis E, Hinrichs B, Magnoni C, Fiorentini C, Majewski S, Ranki A, Stockfleth E, Proby C, on behalf of the EPIDERM Group. 2012. Known and potential new risk factors for skin cancer in European populations: A multicentre case-control study. Br J Dermatol 167:1-13.

Diepgen Tl, Mahler V. 2002. The epidemiology of skin cancer. Br J Dermatol 146:1-6.

Elias PM, Williams ML. 2013. Re-appraisal of current theories for the development and loss of epidermal pigmentation in hominins and modern humans. J Hum Evol 64:687-692.

Ellison TI, Smith MK, Gilliam AC, MacDonald PN. 2008. Inactivation of the vitamin $\mathrm{D}$ receptor enhances susceptibility of murine skin to UV-induced tumorigenesis. J Invest Dermatol 128:2508-2517.

Engholm G, Ferlay J, Christensen N, Johannesen TB, Klint ̊, Køtlum JE, Milter MC, Ólafsdóttir E, Pukkala E, Storm HH. NORDCAN: cancer incidence, mortality, prevalence and survival in the Nordic countries, version 5.3 (25.04.2013). Association of the Nordic Cancer Registries, Danish Cancer Society. Online: http://www.ancr.nu . Accessed August 2, 2013.

Epstein EH. 2008. Basal cell carcinomas: Attack of the hedgehog. Nat Rev Cancer 8:743-754.

Finch C. 2012. Evolution of the human lifespan, past, present, and future: Phases in the evolution of human life expectancy in relation to the inflammatory load. Proc Am Philos Soc 156: 9-43.

Finch CE. 2010. Evolution of the human lifespan and diseases of aging: Roles of infection, inflammation, and nutrition. Proc Natl Acad Sci USA 107:1718-1724.

Gaulin S, McBurney D. 2003. Evolutionary psychology. New York: Prentice Hall.

Gloster HM Jr., Neal K. 2006. Skin cancer in skin of color. J Am Acad Dermatol 55:741-760.

Greenman C, Stephens P, Smith R, Dalgliesh GL, Hunter C, Bignell G, Davies H, Teague J, Butler A, Stevens C, Edkins S, O'Meara S, Vastrik I, Schmidt EE, Avis T, Barthorpe S, Bhamra G, Buck G, Choudhury B, Clements J, Cole J, Dicks E, Forbes S, Gray K, Halliday K, Harrison R, Hills K, Hinton J, Jenkinson A, Jones D, Menzies A, Mironenko T, Perry J, Raine K, Richardson D, Shepherd R, Small A, Tofts C, Varian J, Webb T, West S, Widaa S, Yates A, Cahill DP, Louis DN, Goldstraw P, Nicholson AG, Brasseur F, Looijenga L, Weber BL, Chiew Y-E, deFazio A, Greaves MF, Green AR, Campbell P, Birney E, Easton DF, Chenevix-Trench G, Tan M-H, Khoo SK, Teh BT, Yuen ST, Leung SY, Wooster R, Futreal PA, Stratton MR. 2007. Patterns of somatic mutation in human cancer genomes. Nature 446:153-158.

Hamilton W. 1964. The genetical evolution of social behavior. J Theor Biol 7:1-52.

Han J, Kraft P, Nan H, Guo Q, Chen C, Qureshi A, Hankinson SE, Hu FB, Duffy DL, Zhao ZZ, Martin NG, Montgomery GW, Hayward NK, Thomas G, Hoover RN, Chanock S, Hunter DJ. 2008. A genome-wide association study identifies novel alleles associated with hair color and skin pigmentation. PLoS Genet 4:e1000074.

Hawkes K, O'Connell JF, Blurton Jones NG, Alvarez H, Charnov EL. 1998. Grandmothering, menopause, and the evolution of human life histories. Proc Natl Acad Sci USA 95: 1336-1339.

Hawkes K, O'Connell JF, Blurton Jones NG. 1997. Hadza women's time allocation, offspring provisioning, and the evolution of long postmenopausal life spans. Curr Anthropol 38:551- 577.
Haynes R, Pearce J, Barnett R. 2008. Cancer survival in New Zealand: Ethnic, social and geographical inequalities. Soc Sci Med 67:928-937.

Hrdy S. 2005. Comes the child before man: How cooperative breeding and prolonged postweaning dependence shaped human potentials. In: Hewlett B, Lamb M, editors. Huntergatherer childhoods: evolutionary, developmental and colonial perspectives. New Brunswick, NJ: Aldine Transaction. p 65-91.

Huang FW, Hodis E, Xu MJ, Kryukov GV, Chin L, Garraway LA. 2013. Highly recurrent TERT promoter mutations in human melanoma. Science 339:957-959.

Ikehata H, Kawai K, Komura J-i, Sakatsume K, Wang L, Imai M, Higashi S, Nikaido O, Yamamoto K, Hieda K, Watanabe M, Kasai H, Ono T. 2008. UVA1 genotoxicity is mediated not by oxidative damage but by cyclobutane pyrimidine dimers in normal mouse skin. J Invest Dermatol 128:2289-2296.

Jablonski NG. 2010. Skin coloration. In: Muehlenbein M, editor. Human evolutionary biology. New York: Cambridge University Press. p 192-213.

Jablonski NG. 2012. The evolution of human skin colouration and its relevance to health in the modern world. J R Coll Physicians Edinb 42:58-63.

Jablonski NG, Chaplin G. 2000. The evolution of human skin coloration. J Hum Evol 39:57-106.

Jablonski NG, Chaplin G. 2010. Human skin pigmentation as an adaptation to UV radiation. Proc Natl Acad Sci USA 107: 8962-8968.

Johnson DS, Yamane S, Morita S, Yonehara C, Wong JH. 2003. Malignant melanoma in non-Caucasians: experience from Hawaii. Surg Clin North Am 83:275-282.

Josephson SC. 2002. Does polygyny reduce fertility?. Am J Hum Biol 14:222-232.

Juzeniene A, Setlow R, Porojnicu A, Steindal AH, Moan J. 2009. Development of different human skin colors: a review highlighting photobiological and photobiophysical aspects. J Photochem Photobiol B 96:93-100.

Kaplan H. 1997. The evolution of the human life course. In: Wachter K, Finch C, editors. Between Zeus and the salmon. Washington, DC: National Academy Press. p 175-211.

Kaplan H, Gurven M. 2007. Longevity among hunter-gatherers: A cross-cultural examination. Pop Dev Rev 33:321-365.

Kaplan H, Gurven M, Winking J, Hooper P, Stieglitz J. 2010. Learning, menopause, and the human adaptive complex. Ann NY Acad Sci 1204:30-42.

Kaplan H, Hill K, Lancaster J, Hurtado AM. 2000. A theory of human life history evolution: Diet, intelligence, and longevity. Evol Anthropol 9:156-185.

Kramer KL. 2005. Children's help and the pace of reproduction: Cooperative breeding in humans. Evol Anthropol 14:224-237.

Lacour JP. 2002. Carcinogenesis of basal cell carcinomas: Genetics and molecular mechanisms. Br J Dermatol 146:17-19.

Lee ML, Tomsu K, Von Eschen KB. 2000. Duration of survival for disseminated malignant melanoma: Results of a metaanalysis. Melanoma Res 10:81-92.

Lemus-Deschamps L, Makin JK. 2012. Fifty years of changes in UV Index and implications for skin cancer in Australia. Int J Biometeorol 56:727-735.

Levitis DA, Burger O, Lackey LB. 2013. The human post-fertile lifespan in comparative evolutionary context. Evol Anthropol: 22:66-79.

Lomas A, Leonardi-Bee J, Bath-Hextall F. 2012. A systematic review of worldwide incidence of nonmelanoma skin cancer. Br J Dermatol 166:1069-1080. 
Lookingbill DP, Lookingbill GL, Leppard B. 1995. Actinic damage and skin cancer in albinos in northern Tanzania: Findings in 164 patients enrolled in an outreach skin care program. J Am Acad Dermatol 32:653-658.

Marlowe FW. 2003. The mating system of foragers in the standard cross-cultural sample. Cross Cult Res 37:282-306.

Melancon T. 1982. Marriage and reproduction among the Yanomamö of Venezuela. Thesis. Pennsylvania State University.

Mervic L. 2012. Time course and pattern of metastasis of cutaneous melanoma differ between men and women. PLoS One 7:e32955.

Moan J, Porojnicu AC, Dahlback A, Setlow RB. 2008. Addressing the health benefits and risks, involving vitamin $\mathrm{D}$ or skin cancer, of increased sun exposure. Proc Natl Acad Sci USA 105:668-673.

Nan H, Kraft P, Hunter DJ, Han J. 2009. Genetic variants in pigmentation genes, pigmentary phenotypes, and risk of skin cancer in Caucasians. Int J Cancer 125:909-917.

Neugut AI, Kizelnik-Freilich S, Ackerman C. 1994. Black-white differences in risk for cutaneous, ocular, and visceral melanomas. Am J Public Health 84:1828-1829.

New Zealand Ministry of Health. Cancer: selected sites 2009, 2010, 2011. Ministry of Health NZ. Online: http:// www.health.govt.nz/publication/cancer-selectedsites-2009-2010-2011. Accessed August 10, 2013.

Olsen CM, Green AC, Neale RE, Webb PM, Cicero RA, Jackman LM, O'Brien SM, Perry SL, Ranieri BA, Whiteman DC, for the QSkin Study. 2012. Cohort profile: The QSkin Sun and Health Study. Int J Epidemiol 41:929-929i.

Pandeya N, Purdie DM, Green Al, Williams G. 2005. Repeated occurrence of basal cell carcinoma of the skin and multifailure survival analysis: Follow-up data from the Nambour Skin Cancer Prevention Trial. Am J Epidemiol 161:748-754.

Peccei J. 2001. Menopause: adaptation or epiphenomenon? Evol Anthropol 10:43-57.

Quevedo WC, Fitzpatrick TB, Pathak MA, Jimbow K. 1975. Role of light in human skin color variation. Am J Phys Anthropol 43:393-408.

Robins A. 1991. Biological perspectives on human pigmentation. Cambridge: Cambridge University Press.

Rünger TM. 2008. CèT transition mutations are not solely UVB-signature mutations, because they are also generated by UVA. J Invest Dermatol 128:2138-2140.

Rees JL. 2004. The genetics of sun sensitivity in humans. Am J Hum Genet 75:739-751.

Scelza B. 2010. Fathers' presence speeds the social and reproductive careers of sons. Curr Anthropol 51:295-303.

Scherer D, Kumar R. 2010. Genetics of pigmentation in skin cancer - A review. Mutat Res 705:141-153.

Sear R, Ruth M. 2008. Who keeps children alive? A review of the effects of kin on child survival. Evol Hum Behav 29:1-18.

Singh A, Park H, Kangsamaksin T, Singh A, Readio N, Morris RJ. 2012. Keratinocyte stem cells and the targets for nonmelanoma skin cancer. Photochem Photobiol 88:1099-1110.

Sneyd MJ, Cox B. 2009. Melanoma in Maori, Asian, and Pacific peoples in New Zealand. Cancer Epidemiol Biomarkers Prev 18:1706-1713.
Soeripto, Jensen OM, Muir CS. 1977. Cancer in Yogyakarta, Indonesia: Relative frequencies. Br J Cancer 36:141-148.

Sosis R, Kress H, Boster J. 2007. Scars for war: Evaluating alternative signaling explanations for cross-cultural variance in ritual costs. Evol Hum Behav 28:234-247.

Stern RS. 2010. Prevalence of a history of skin cancer in 2007: Results of an incidence-based model. Arch Dermatol 146:279- 282.

Tang JY, Xiao TZ, Oda Y, Chang KS, Shpall E, Wu A, So P-L, Hebert J, Bikle D, Epstein EH. 2011. Vitamin D3 inhibits hedgehog signaling and proliferation in murine basal cell carcinomas. Cancer Prev Res 4:744-751.

Tewari A, Sarkany RP, Young AR. 2012. UVA1 induces cyclobutane pyrimidine dimers but not 6-4 photoproducts in human skin in vivo. J Invest Dermatol 132:394-400.

Tucker MA. 2008. Is sunlight important to melanoma causation?. Cancer Epidemiol Biomarkers Prev 17:467-468.

van der Pols JC, Russell A, Bauer U, Neale RE, Kimlin MG, Green AC. 2013. Vitamin D status and skin cancer risk independent of time outdoors: 11-year prospective study in an Australian community. J Invest Dermatol 133:637-641.

Vazquez AI, de los Campos G, Klimentidis YC, Rosa GJM, Gianola D, Yi N, Allison DB. 2012. A comprehensive genetic approach for improving prediction of skin cancer risk in humans. Genetics 192:1493-1502.

Voland E. 1998. Evolutionary ecology of human reproduction. Annu Rev Anthropol 27:347-374.

Wabinga HR, Parkin DM, Wabwire-Mangen F, Nambooze S. 2000. Trends in cancer incidence in Kyadondo Country, Uganda, 1960-1997. Br J Cancer 82:1585-1592.

Weir HK, Marrett LD, Cokkinides V, Barnholtz-Sloan J, Patel P, Tai E, Jemal A, Li J, Kim J, Ekwueme DU. 2011. Melanoma in adolescents and young adults (ages 15-39 years): United States, 1999-2006. J Am Acad Dermatol 65:S38.e1S38.e13.

Williams GC. 1957. Pleiotropy, natural selection, and the evolution of senescence. Evolution 11:32-39.

Williams JD, Jacobson EL, Kim H, Kim M, Jacobson MK, Stanger O. 2012. Folate in skin cancer prevention: Water soluble vitamins. Dordrecht: Springer Netherlands. $p$ 181- 197.

Wood J, Milner GJ, Harpending H, Weiss K. 1992. The osteological paradox: The problem of inferring prehistoric health from skeletal samples. Curr Anthropol 33:343-370.

Wu X-C, Eide MJ, King J, Saraiya M, Huang Y, Wiggins C, Barnholtz-Sloan JS, Martin N, Cokkinides V, Miller J, Patel P, Ekwueme DU, Kim J. 2011. Racial and ethnic variations in incidence and survival of cutaneous melanoma in the United States, 1999-2006. J Am Acad Dermatol 65:S26. e1-S26.e13.

Yakubu A, Mabogunje O. 1995. Skin cancer of the head and neck in Zaria, Nigeria. Acta Oncol 34:469-471.

Yakubu A, Mabogunje OA. 1993. Skin cancer in African albinos. Acta Oncol 32:621-622.

Zinser GM, Sundberg JP, Welsh J. 2002. Vitamin D3 receptor ablation sensitizes skin to chemically induced tumorigenesis. Carcinogenesis 23:2103-2109. 